Domagoj VOLAREVIĆ

Katolički bogoslovni fakultet u Splitu

domagoj.volarevic@du.t-com.hr
UDK 272-282.7:003.344

091.14(497.5Split)"12/13"

Izvorni znanstveni članak

Primljen: 4 ožujka 2019.

Prihvaćen: 9. listopada 2019.

\title{
RUKOPIS 463 KAPTOLSKOGA ARHIVA U SPLITU (KAS 463)
}

U Kaptolskome arhivu Splitsko-makarske nadbiskupije pod kataloškim brojem 463 nalazi se kodeks od pergamene pisan goticom. ${ }^{1}$ Popis arhivskoga gradiva bilješkom o signaturi dokazuje da je rukopis ranije bio poznat $i$, tom logikom, trebao je biti u slijedu knjiga i fascikli na određenomu mjestu, ali ga nije bilo. Kako to pri otkrićima obično biva, sasvim slučajno je ponovno pronađen koncem 2017. godine. Ispočetka se držalo da se radi o potpuno nepoznatomu srednjovjekovnome kodeksu. U veljači 2018. utvrdilo se da je pronađeni rukopis upravo onaj koji je otprije bio arhiviran u Katalogu pod brojem 463. Do otkrića je došlo tako da su - zajedno s rukopisom koji sadrži životopis sv. Klementa pape, iz 16. stoljeća - uočeni neki stariji dijelovi. Ti dijelovi po stilu pisma i podlozi na kojoj je pisano nisu mogli pripadati u izvorni rukopis o životopisu sv. Klementa nego su puno stariji. Primarnom analizom utvrdilo se da je riječ o srednjovjekovnomu liturgijskome kodeksu. Kodeks je restauriran i čeka uvezivanje u tvrde korice. Nakon restauratorskih zahvata napravili smo liturgijsku i kodikološku analizu koja je pomogla ispravnom uređenju slijeda folija u kodeksu. Rezultate potonjih analiza donosimo kao doprinose u nastavku.

Ključne riječi: kodeks, liturgija, himnar, antifonar, kapitular, kodikologija

\section{TEHNIČKE ZNAČAJKE}

\subsection{Pismo i jezik}

Srednjovjekovni liturgijski kodeksi zapadnih liturgija $\bar{a}^{2}$ redovito su pisani latinskim jezikom, kao što je slučaj i kod našega kodeksa. ${ }^{3}$ Riječ je o latinskomu liturgijskome jeziku, sa svojim specifičnim nazivima liturgijskih čina i vremenā. I kodeks 463 pisan je goticom. ${ }^{4}$

1 Ovaj rad nastao je - potporom Hrvatske zaklade za znanost - unutar projekta IP 6619 (Cromuscodex70), voditeljica projekta: dr. sc. Hana Breko-Kustura.

2 Iako je prevladavajući liturgijski tip na zapadu rimska liturgija, koristimo ovu sintagmu kako bismo označili da postoji još zapadnih liturgija (ambrozijanska, hispano-mozarapska i dr.).

3 Značajne »iznimke« su, ako ih tako smijemo nazvati, rimski časoslovi na crkvenoslavenskomu jeziku.

${ }^{4}$ Gotica je stil pisma koji se počeo razvijati iz karolinške minuskule u drugoj polovini 11. stoljeća, prvotno u sjevernoj Francuskoj i Njemačkoj te u Engleskoj. Značajke gotice su kraći potezi perom i stilizacija s naglašenom okomitošću slova. Usp. PETRUCCI 1992: 128. 
Preliminarni pregled kodeksa otkriva rad barem četvorice pisara na prepisivanju pojedinih dijelova kodeksa. Njima moramo dodati i vjerojatnoga minijaturista koji je napravio veliki inicijal na početku Himnarija. ${ }^{5}$ Stilovi gotice mogu se svesti pod zajednički nazivnik gotica rotunda. ${ }^{6}$ Prvi i stariji dio kodeksa sadrži goticu u ranijoj fazi, tada još označavanu kao littera moderna. ${ }^{7}$ Drugi dio je pisan razvijenim stilom gotice. Različiti pisari, kao i mogući različiti predlošci (egzemplari) iz kojih je prepisivan kodeks $K A S 463$, vjerojatan su uzrok i pravopisnih nepreciznosti koje se odmah mogu uočiti u naslovima pisanim crvenom bojom. Najupečatljiviji primjer je nedosljednost u pisanju pojma hymnus, jer ćemo u kodeksu naići i na oblik ymnus, bez početnoga $h$.

Potezi perom razmjerno su blagi i pokazuju izvjesnu eleganciju, kao što se može vidjeti u primjeru slova $m$ :

\section{canamus mit.}

Na primjeru slova $m$ (u lat. canamus) može se vidjeti kako su »grane« slova $» n \ll \mathrm{i} » m \ll$ povučene blago i oblo, što upućuje na talijanski stil i goticu rotundu. ${ }^{8}$

\subsection{Kodikološka struktura}

Kodeks je pronađen krajem 2017. godine. U zatečenom stanju sadržavao je 75 folija koje nisu bile uvezane. Potom je dan na restauraciju. ${ }^{9}$ Očišćen i uređen nije uvezivan. Iako je na listovima već postojala olovkom upisana numeracija, restauratori su naknadno i, zasad privremeno, upisali numeraciju arapskim brojkama točno onim redoslijedom kako su bili složeni kada su pronađeni. Metodama liturgijske i kodikološke analize utvrdili smo da taj redoslijed listova nije izvoran. Većina listova je u razmjerno dobrom stanju. Neki su oštećeni na način da su otrgnuti dijelovi lista. Na nekima je tekst izblijedio pa je teže, ili uopće nije čitljiv.

\footnotetext{
5 Veliki inicijal na početku Himnarija f. 33r (ili f. 27r prema izvornijoj paginaciji).

6 PETRUCCI 1992: 135.

7 Za razliku od antiqua, što se odnosilo na karolinšku minuskulu. Usp. BATTELLI 2015: 204-205.

8 Za razliku od njemačkoga (transalpinskoga) stila koji je oštriji u potezima. Usp. BATTELLI 2015: 211

9 Restauraciju je vodila prof. Nevenka Perić Klarić, viša konzervatorica-restauratorica iz Državnoga arhiva u Splitu.
} 


\subsubsection{Redoslijed listova}

Listovi su uglavnom složeni u kvaternione ${ }^{10}$ (lat. quaternion), što odgovara načinu uveza knjiga u srednjemu vijeku. ${ }^{11} \mathrm{U}$ trenutku pronalaska prvi je sveš-

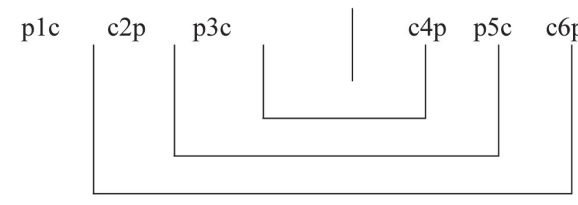

$\mathrm{p} 7 \mathrm{c}$

$\mathrm{p} 8 \mathrm{c}$

F. I

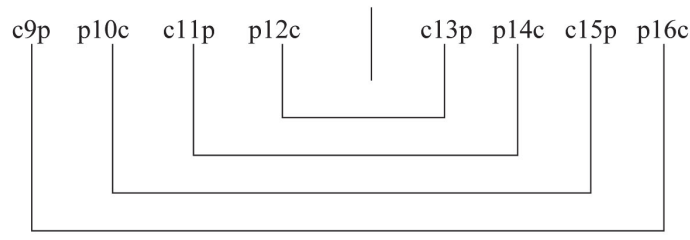

\begin{tabular}{lllll|llll} 
F. II $\quad \mathrm{c} 17 \mathrm{p}$ & $\mathrm{p} 18 \mathrm{c}$ & $\mathrm{c} 19 \mathrm{p}$ & $\mathrm{p} 20 \mathrm{c}$ & $\mathrm{c} 21 \mathrm{p}$ & $\mathrm{p} 22 \mathrm{c}$ & $\mathrm{c} 23 \mathrm{p}$ & $\mathrm{p} 24 \mathrm{c}$
\end{tabular}

\begin{tabular}{lllll|llll} 
F. III & $\mathrm{c} 25 \mathrm{p}$ & $\mathrm{p} 26 \mathrm{c}$ & $\mathrm{c} 27 \mathrm{p}$ & $\mathrm{p} 28 \mathrm{c}$ & $\mathrm{c} 29 \mathrm{p}$ & $\mathrm{p} 30 \mathrm{c}$ & $\mathrm{c} 31 \mathrm{p}$ & $\mathrm{p} 32 \mathrm{c}$
\end{tabular}

\begin{tabular}{lllll|llll} 
F.IV & $\mathrm{c} 33 \mathrm{p}$ & $\mathrm{p} 34 \mathrm{c}$ & $\mathrm{c} 35 \mathrm{p}$ & $\mathrm{p} 36 \mathrm{c}$ & $\mathrm{c} 37 \mathrm{p}$ & $\mathrm{p} 38 \mathrm{c}$ & $\mathrm{c} 39 \mathrm{p}$ & $\mathrm{p} 40 \mathrm{c}$
\end{tabular}

F. V c41p $\mid \mathrm{p} 42 \mathrm{c}$

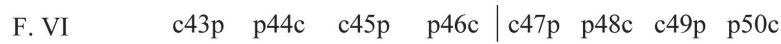

\begin{tabular}{lllll|llll} 
F. VII $\quad \mathrm{c} 51 \mathrm{p}$ & $\mathrm{p} 52 \mathrm{c}$ & $\mathrm{c} 53 \mathrm{p}$ & $\mathrm{p} 54 \mathrm{c}$ & $\mathrm{c} 55 \mathrm{p}$ & $\mathrm{p} 56 \mathrm{c}$ & $\mathrm{c} 57 \mathrm{p}$ & $\mathrm{p} 58 \mathrm{c}$
\end{tabular}

F. VIII $\quad$ c59p p60c c61p p62c|c63p p64c c65p p66c

\begin{tabular}{lllll|llll} 
F. IX $\quad c 67 p$ & p68c & $c 69 p$ & p70c & $\mathrm{c} 71 \mathrm{p}$ & $\mathrm{p} 72 \mathrm{c}$ & $\mathrm{c} 73 \mathrm{p}$ & $\mathrm{p} 74 \mathrm{c}$
\end{tabular}

${ }^{10}$ Kvaternion (lat. quaternion) je sveščić u kodeksu koji se sastoji od četiriju dvolisnica na način da su četiri lista (obično pergamene) stavljeni jedan na drugi te potom preklopljeni kao sveščić koji ima osam listova, odnosno šesnaest stranica. Usp. MANIACI 1996: 134.

11 Takva metoda je uglavnom ostala nepromijenjena do danas, tj. arak je osnovna jedinica kojom se uvezuju knjige. 
čić bio sastavljen od 6 listova (tri dvolisnice ili lat. ternion). Nakon tih prvih šest listova bila su dva samostalna lista. Potom se u kodeksu nalazilo devet sveščića (lat. fasciculus), od kojih je peti bio samo jedna dvolisnica (lat. monion). Shematski - s privremenom numeracijom - to je izgledalo na sljedeći način:

Da bi se razumjele netom prikazane sheme, potrebno je poznavati tzv. Gregorijevo pravilo ili Gregoryevu ${ }^{12}$ metodu. Naime, Gregory je pomnjivim proučavanjem starih kodeksa uočio zakonitosti u njihovoj izradi i strukturi te potom utvrdio neke metodološke sustave za njihovo proučavanje koji su i danas relevantni. Pojam Gregorijevo pravilo odnosi se na redoslijed pergamenskih listova srednjovjekovnoga kodeksa. Gregory je utvrdio da su listovi poredani i uvezani u sveščiće (redovito quaternione), preteče suvremenih araka, i to na specifičan način. Budući da je pergamena obrađena životinjska koža na kojoj se, nakon obrade, može pisati, jedna je strana te kože bila »vanjska« pod dlakom (lat. pellis 'koža', skr. $p$ ), a druga »unutrašnja u uz koju je bilo tkivo, tj. životinjsko meso (lat. caro 'meso', skr. c). Sveščić (lat. fasciculum) uvijek je tako složen da u izvornomu stanju kod dva lista koja se nalaze jedan do drugoga strana pellis se uvijek dodiruje, tj. naslanja na stranu pellis od sljedećega lista, što vrijedi i za stranu carnis. U shematskomu prikazu uz brojeve listova označene su strane -vanjska (koža, pellis) i unutrašnja (meso, caro). Ako se u kodeksu strana pellis naslanja na stranu carnis (ili obratno), kodeks nije u izvornome stanju i pretrpio je intervente tijekom povijesti (usp. GREGORY 1900).

Primjenjujući tzv. Gregorijevo pravilo ili metodu, odmah su utvrđene nedosljednosti u redoslijedu, koje su potvrdile da ovakav raspored sveščića i listova nije izvoran. Rečene nedosljednosti u strukturi dokazuju da je kodeks trpio naknadne intervente. To i nije toliko čudno. Srednjovjekovni su liturgijski kodeksi dugo bili u uporabi te korišteni i za molitvu i za prepisivanje. Stoga naknadni interventi nisu neobični. Nije neobično ni to što su listovi ispremiješani, pogotovo ako je uvez kodeksa olabavio ili se raspao pa je u zatečenomu stanju složen i ostavljen na čuvanje.

Prvi sveščić (u zatečenomu stanju ternion) kao i dvolisnica (f. 41 i 42) pokazivali su nedosljednosti. Slijed teksta na tim listovima pokazuje da je prvi sveščić izvorno bio između f. 41 i 42, i to na način da je f. 41 bio prvi list u kvaternionu, f. 1 drugi, te, susljedno, f. 42 posljednji. Grafička je shema nanovo uspostavljena izvornoga sveščića sljedeća:

$$
\begin{array}{llll|llll}
\mathrm{c} 41 \mathrm{p} & p 1 c & c 2 p & p 3 c & c 4 p & p 5 c & c 6 p & \mathrm{p} 42 \mathrm{c}
\end{array}
$$

${ }^{12}$ Caspar René Gregory (1846. - 1917.), američki teolog i bibličar njemačkoga podrijetla. Specijalizirao je tekstualnu kritiku Novoga zavjeta. Pomnjivim proučavanjem starih kodeksa uočio je zakonitosti u njihovoj izradi i strukturi te potom utvrdio neke metodološke sustave za njihovo proučavanje koji su na snazi i danas. 
Očito je tijekom premještanja došlo do raslojavanja pojedinih sveščića, vjerojatno zbog neuvezanosti. U jednom se trenutku listove koji su ispali jednostavno stavilo na početak kodeksa te je sve pohranjeno na čuvanje.

Kodikološko stanje koje smo upravo predstavili najbliže je izvornomu, koje - zbog nepotpunosti kodeksa - nije moguće potpuno rekonstruirati. Nedvojbena potvrda bliskosti izvornomu stanju jest i to što je na listu koji je u restauraciji označen s f. 33, upisan broj lista 27. Ova potonja oznaka upisana je od nekadašnjega knjižničara. Razlika od 6 listova nastala je zbog ispadanja neuvezanih listova koji su - nakon pronalaska - stavljeni na početak kodeksa. Što se tiče ostatka kodeksa, predstavili smo u shemi da su sveščići tekstno, tematski i kodikološki pravilno složeni.

\subsubsection{Listovi s privremenom numeracijom $f .7$ if. 8}

Listovi koji su tijekom restauracije obilježeni kao f. 7 i f. 8. također ukazuju na nedosljednosti. Slijed teksta kasnije je pokazao da je onaj označeni kao f. 8, dio sveščića (vjerojatno kvaterniona) koji nismo pronašli. Stil pisma i notacije dovode do zaključka da je to dio sveščića koji je izvorno pripadao kodeksu. Osim rečenoga lista, od sveščića ne postoji nikakav drugi trag u Kaptolskomu arhivu u Splitu. Možemo zaključiti da je izgubljen. Proučavajući stil pisma na listu f. 7, nameću se dvije hipoteze: taj list je dio nekog drugog, također nama danas nepoznatoga kodeksa, ili je dio kasnijih dopuna koje su postupno prepisivane te pridruživane izvornomu kodeksu. ${ }^{13}$

Zaključujemo da je taj list bio uzrok zabune i privremenoga zagubljenja kodeksa. Naime, privremeni f. 7 na svojoj verso strani sadrži himan u čast sv. Klementa, pape i mučenika. U uvodnim crtama istaknuli smo kako se kodeks $K A S 463$ nalazio u Arhivu zajedno s kasnijim životopisom sv. Klementa, te je to vjerojatno jedan od bibliotekara, vidjevši himan u čast sv. Klementa, cijeli kodeks stavio uz životopis sv. Klementa. Držimo da su, osim toga, i oblik i veličina lista, dosta slični kodeksu $K A S 463$, bili povod nekadašnjem arhivistu da je taj list i cijeli kodeks složio po tematskoj i grafijskoj sličnosti.

O tome je li taj list (f. 7 prema numeraciji u zatečenomu stanju) pripadao kodeksu $K A S 463$, ili nekom drugom, govori nekoliko okolnosti. Taj list ima drukčiji stil pisma od pisma ostalih himana u kodeksu. Dakle, različit je stil pisma - što bi značilo da su različiti pisari - a i margine su različite od dijela koji sadrži himne. Nadalje, u himnima su inicijali pisani crvenom tintom i ukrašeni su. Na f. 7 napisani su jednostavno i bez ukrasa, a izmjenjuju se crve-

\footnotetext{
${ }^{13}$ Nije neuobičajeno da se pri nadopuni srednjovjekovnih liturgijskih kodeksa novijim »materijalima« za slavlja u kasnijim vremenima (ali i dalje razmjerno bliskim vremenu nastanka) nije obaziralo na impostaciju i ujednačen izgled stranica sa starijim dijelovima. Usp. VOGEL 1986: 315.
} 
na i plava tinta, što upućuje na to da je taj list ipak bio dio nekog drugoga, nama nepoznata, kodeksa. $\mathrm{K}$ tome, ni različiti pisari, pa ni različita tinta, nisu sigurni pokazatelj da je to bio dio drugoga kodeksa. Mnogi kodeksi nastali su prepisivačkim radom više pisara. Ipak, numerička nas oznaka upućuje na drugi trag: na gornjoj margini lista po sredini je crvenom tintom rimskim brojem upisano »CCXXIII«. Ni na jednom listu kodeksa KAS 463 nema niti jednoga traga srednjovjekovne folijacije, pogotovo pisanih podebljanim slovima i crvenom tintom. Ako bi ovo bili dijelovi istoga kodeksa, može se pretpostaviti da bi i listovi prije numeriranoga morali biti označeni na isti, ili sličan način. Dio koji nije označen, po stilu pisma je nešto stariji, pa se ponovno dolazi do zaključka da je ovaj list bio dio drugoga kodeksa različita od našega.

\subsubsection{Impostacija stranice}

Shematski izgled stranice kodeksa je sljedeći (mjere su u mm):

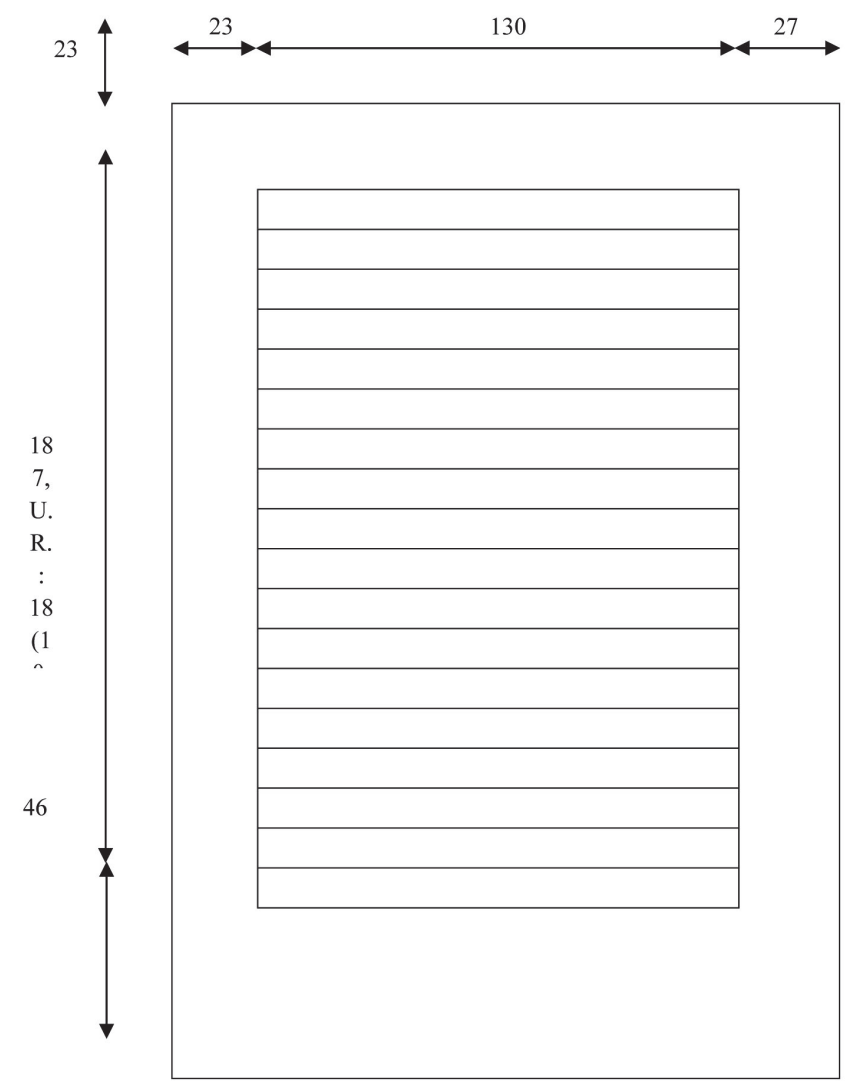


Osim notnih crtovlja, na mnogim su stranicama više nego vidljivi lagani potezi crta koji su određivali margine kao i prostor pisanja na listu. Margine su razmjerno pravilne; tamo gdje bi riječ pri kraju reda bila predugačka, njezin se nastavak ili ostatak pisao u sljedeći red.

\section{LITURGIJSKA STRUKTURA I SADRŽAJ}

Kodikološka struktura utvrdila je da je kodeks nepotpun. Nakon uspostave oblika kodeksa za koji je ustanovljeno da je najbliži izvornoj strukturi, moguće je napraviti i liturgijsku analizu vodeći računa o sveščiću koji je bio rastavljen, pa ponovno sastavljen i umetnut na izvorno mjesto u slijedu sveščića i folija. Dva zasebna lista, koja su sačuvana od prethodnih sveščića, stavljena su na odgovarajuća mjesta na kojima su izvjesno stajala u izvornome stanju. Prema tome, list koji sadrži antifone za pozivnik (lat. invitatorium) ostavljen je na početku kodeksa, jer strukturalno i tematski odgovara sadržaju koji slijedi i koji je sačuvan. List koji sadrži dio sekvencije u čast sv. Klementu stavljen je na kraj kodeksa. Nakon svih preslagivanja listova i sveščića konačno možemo zaključiti da se kodeks sastoji od devet pravilno složenih sveščića (F. I-IX) u formi kvaterniona i dva zasebna lista koji su sačuvani od izgubljenih sveščića.

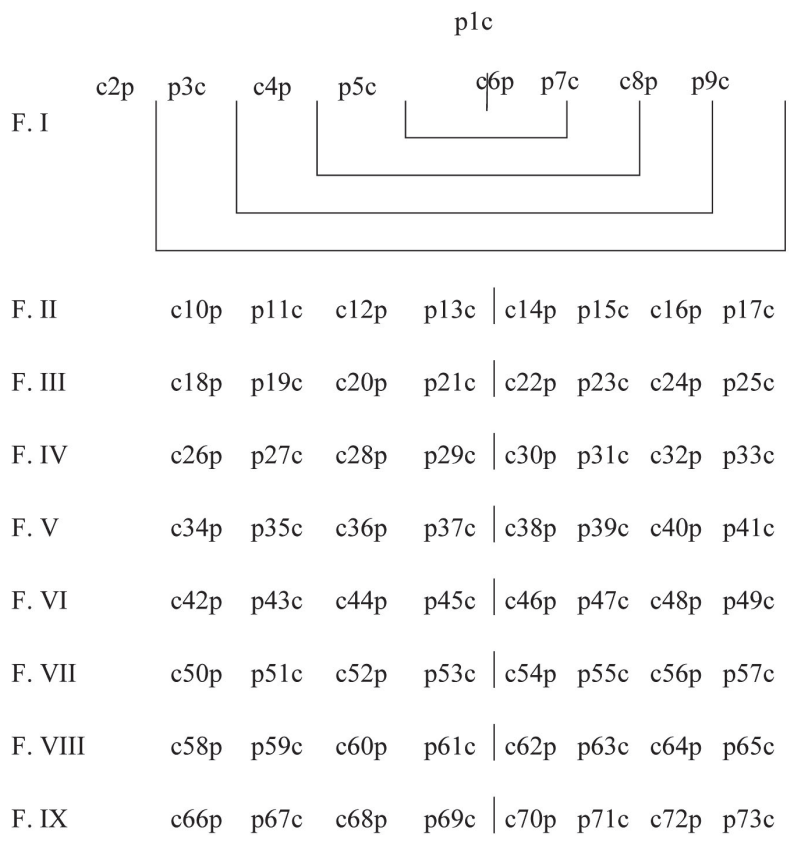

$$
\mathrm{p} 74 \mathrm{c}
$$


List označen f. 7 u privremenoj numeraciji postavljenoj od restauratora nismo ovdje uzeli u obzir, jer nije bio dio izvornoga kodeksa. Od izvornoga kodeksa sačuvana su 74 lista. Zbog zagubljenosti te raslojenosti kodeksa i ponovnoga nedavnoga označivanja listova, u paginaciji je stvorena izvjesna »zbrka«, o kojoj je potrebno itekako voditi računa te ju je potrebno ispraviti. Liturgijsku strukturu kodeksa ovdje donosimo na način da smo u prvi stupac stavili brojeve listova onako kako smatramo da su bili izvorno složeni, odnosno kako smo utvrdili da bi trebala biti izvorna numeracija. U drugome, središnjemu stupcu, naslovi su sadržajnih jedinica. Treći stupac donosi zatečeno stanje listova nakon otkrića i onako kako ih je restaurator privremeno brojčano označio.

\subsection{Kodeks $K A S 463$ - tablični prikaz sadržaja}

\begin{tabular}{|c|c|c|}
\hline f. $1 \mathrm{r}$ & In sancti Antonii - hymnus & f. $8 \mathrm{r}$ \\
\hline & De sancto Francisco & \\
\hline \multirow[t]{6}{*}{ f. $1 \mathrm{v}$} & In duplicibus & f. $8 \mathrm{v}$ \\
\hline & In semiduplicibus & \\
\hline & In festis simplicibus & \\
\hline & In diebus dominicis & \\
\hline & In festis ... oficialibus diebus & \\
\hline & Sabbato septuagesimae & \\
\hline \multirow[t]{4}{*}{ f. $2 r$} & Dominica prima de Adventu & f. $9 \mathrm{r}$ \\
\hline & Feria secunda-invitatorium & \\
\hline & Dominica secunda - invitatorium & \\
\hline & Dominica tertia - invitatorium & \\
\hline \multirow[t]{4}{*}{ f. $2 \mathrm{v}$} & Feria quarta quattuor temporum - invitatorium & f. $9 \mathrm{v}$ \\
\hline & Dominica quarta - invitatorium & \\
\hline & In vigilia natalis Domini - invitatorium & \\
\hline & In Natali Domini - invitatorium & \\
\hline \multirow[t]{4}{*}{ f. $3 r$} & In festo sancti Stephani - invitatorium & f. $10 \mathrm{r}$ \\
\hline & In Epyphania Domini-invitatorium & \\
\hline & Dominica prima post Epyphania - invitatorium & \\
\hline & Aliud-invitatorium & \\
\hline \multirow[t]{2}{*}{ f. $3 v$} & Aliud-invitatorium & f. $10 \mathrm{v}$ \\
\hline & Aliud-invitatorium & \\
\hline
\end{tabular}




\begin{tabular}{|c|c|c|}
\hline & Aliud-invitatorium & \\
\hline \multirow[t]{6}{*}{ f. $4 \mathrm{r}$} & Aliud-invitatorium & f. $11 \mathrm{r}$ \\
\hline & Aliud-invitatorium & \\
\hline & Feria secunda - invitatorium & \\
\hline & Feria tertia-invitatorium & \\
\hline & Feria quarta - invitatorium & \\
\hline & Feria quinta - invitatorium & \\
\hline \multirow[t]{4}{*}{ f. $4 \mathrm{v}$} & Feria sexta-invitatorium & f. $11 \mathrm{v}$ \\
\hline & Sabbato invitatorium & \\
\hline & Dominica prima in quadragesimae - invitatorium & \\
\hline & Dominica secunda - invitatorium & \\
\hline \multirow[t]{3}{*}{ f. $5 \mathrm{r}$} & Dominica tertia - invitatorium & f. $12 \mathrm{r}$ \\
\hline & Dominica quarta - invitatorium & \\
\hline & Dominica quinta de Passione - invitatorium & \\
\hline \multirow[t]{5}{*}{ f. $5 \mathrm{v}$} & Dominica in ramis palmarum - invitatorium & f. $12 \mathrm{v}$ \\
\hline & Dominica resurectionis Domini - invitatorium & \\
\hline & In Ascensione Domini - invitatorium & \\
\hline & $<$ In ferialibus diebus $>$ & \\
\hline & In Pentecosten invitatorium & \\
\hline \multirow[t]{3}{*}{ f. $6 \mathrm{r}$} & In conversione sancti Pauli apostoli - invitatorium & f. $13 \mathrm{r}$ \\
\hline & In purificatuone beatae Mariae - invitatorium & \\
\hline & In cathedra sancti Petri apostoli - introitus & \\
\hline \multirow[t]{3}{*}{ f. $6 \mathrm{v}$} & In Annuntiatione sanctae Mariae - invitatorium & f. $13 v$ \\
\hline & In sanctorum a Pascha usque ad Pentecosten - invitatorium & \\
\hline & In sancti Antonii-invitatorium & \\
\hline \multirow[t]{3}{*}{ f. $7 \mathrm{r}$} & In nativitate sancti Iohannis baptistae - invitatorium & f. $14 \mathrm{r}$ \\
\hline & In festo sanctae Mariae Magdalenae - invitatorium & \\
\hline & In sancti Laurentii - invitatorium & \\
\hline \multirow[t]{3}{*}{ f. $7 \mathrm{v}$} & In Assumptione Virginis Mariae - invitatorium & f. $14 \mathrm{v}$ \\
\hline & In Nativitate Beatae Virginis Mariae - invitatorium & \\
\hline & In Sancti Michaeli Archangeli-invitatorium & \\
\hline \multirow[t]{3}{*}{ f. $8 \mathrm{r}$} & In sancti Francisci (confessoris) - invitatorium & f. $15 \mathrm{r}$ \\
\hline & In festo omnium sanctorum - invitatorium & \\
\hline & In sancti Martini (confessoris) - invitatorium & \\
\hline
\end{tabular}




\begin{tabular}{|c|c|c|}
\hline f. $8 \mathrm{v}$ & In natali apostolorum - invitatorium & f. $15 \mathrm{v}$ \\
\hline & Aliud-invitatorium & \\
\hline & In unius martyris et (?)- invitatorium & \\
\hline f. $9 \mathrm{r}$ & In confessoribus - invitatorium & f. $16 \mathrm{r}$ \\
\hline & In sanctarium virginum - invitatorium & \\
\hline & In anniversario dedicationis ecclesiae - invitatorium & \\
\hline & Pro defunctis - invitatorium & \\
\hline f. $9 v$ & & f. $16 \mathrm{v}$ \\
\hline f. $10 \mathrm{r}$ & & f. $17 \mathrm{r}$ \\
\hline f. $10 \mathrm{v}$ & & f. $17 \mathrm{v}$ \\
\hline f. $11 \mathrm{r}$ & & f. $18 \mathrm{r}$ \\
\hline f. $11 \mathrm{v}$ & & f. $18 \mathrm{v}$ \\
\hline f. $12 \mathrm{r}$ & & f. $19 \mathrm{r}$ \\
\hline f. $12 \mathrm{v}$ & & f. $19 v$ \\
\hline f. $13 r$ & & f. $20 \mathrm{r}$ \\
\hline f. $13 v$ & & f. $20 \mathrm{v}$ \\
\hline f. $14 \mathrm{r}$ & & f. $21 \mathrm{r}$ \\
\hline f. $14 \mathrm{v}$ & In Nativitatie Domini - invitatorium & f. $21 \mathrm{v}$ \\
\hline f. $15 \mathrm{r}$ & & f. $22 \mathrm{r}$ \\
\hline f. $15 \mathrm{v}$ & & f. $22 \mathrm{v}$ \\
\hline f. $16 \mathrm{r}$ & Invitatorium (Sancti Stephani ?) & f. $23 \mathrm{r}$ \\
\hline f. $16 \mathrm{v}$ & & f. $23 v$ \\
\hline f. $17 \mathrm{r}$ & & f. $24 \mathrm{r}$ \\
\hline f. $17 \mathrm{v}$ & & f. $24 \mathrm{v}$ \\
\hline f. $18 \mathrm{r}$ & Invitatorium (Sancti Iohannis ?) & f. $25 \mathrm{r}$ \\
\hline f. $18 \mathrm{v}$ & & f. $25 \mathrm{v}$ \\
\hline f. $19 \mathrm{r}$ & & f. $26 \mathrm{r}$ \\
\hline f. $19 v$ & Invitatorium aliud & f. $26 \mathrm{v}$ \\
\hline f. $20 \mathrm{r}$ & & f. $27 \mathrm{r}$ \\
\hline f. $20 \mathrm{v}$ & & f. $27 \mathrm{v}$ \\
\hline f. $21 \mathrm{r}$ & Invitatorium aliud & f. $28 \mathrm{r}$ \\
\hline f. $21 \mathrm{v}$ & & f. $28 \mathrm{v}$ \\
\hline f. $22 r$ & & f. $29 \mathrm{r}$ \\
\hline f. $22 v$ & Invitatorium & f. $29 v$ \\
\hline
\end{tabular}




\begin{tabular}{|c|c|c|}
\hline f. $23 r$ & & f. 30r \\
\hline f. $23 \mathrm{v}$ & & f. $30 \mathrm{v}$ \\
\hline f. $24 \mathrm{r}$ & Invitatorium & f. $31 \mathrm{r}$ \\
\hline f. $24 \mathrm{v}$ & & f. $31 v$ \\
\hline f. $25 \mathrm{r}$ & & f. $32 \mathrm{r}$ \\
\hline f. $25 \mathrm{v}$ & In ferialibus diebus - invitatorium & f. $32 \mathrm{v}$ \\
\hline f. $26 r$ & Incipit hymnarius. Primo dierum omnium & f. $33 \mathrm{r}$ \\
\hline f. $26 v$ & Ad Laudes & f. $33 \mathrm{v}$ \\
\hline f. $27 \mathrm{r}$ & Ab octava Pentecosten usque ad Kalendas Octobris ad Nonam & f. $34 \mathrm{r}$ \\
\hline f. $27 \mathrm{v}$ & In Laudibus & f. $34 \mathrm{v}$ \\
\hline f. $28 \mathrm{r}$ & Ad Primam & f. $35 \mathrm{r}$ \\
\hline \multirow[t]{2}{*}{ f. $28 \mathrm{v}$} & Ad Ter[c]iam & f. $35 v$ \\
\hline & Ad Sextam & \\
\hline \multirow[t]{2}{*}{ f. $29 \mathrm{r}$} & Ad Nonam & f. $36 \mathrm{r}$ \\
\hline & Ad Vesperas & \\
\hline \multirow[t]{2}{*}{ f. $29 \mathrm{v}$} & Ad Completorium & f. $36 \mathrm{v}$ \\
\hline & Feria secunda. Ad Nocturnum ymnus & \\
\hline f. $30 r$ & In Laudibus & f. $37 \mathrm{r}$ \\
\hline f. $30 v$ & & f. $37 \mathrm{v}$ \\
\hline f. $31 \mathrm{r}$ & Ad Vesperas & f. $38 \mathrm{r}$ \\
\hline \multirow[t]{2}{*}{ f. $31 \mathrm{v}$} & Feria Tertia. Ymnus ad Nocturnum & f. $38 \mathrm{v}$ \\
\hline & In Laudibus & \\
\hline f. $32 \mathrm{r}$ & Ad Vesperas & f. $39 \mathrm{r}$ \\
\hline f. $32 v$ & Feria quarta. Ad Nocturnum & f. $39 \mathrm{v}$ \\
\hline \multirow[t]{2}{*}{ f. $33 \mathrm{r}$} & Ad Laudes & f. $40 \mathrm{r}$ \\
\hline & Ad Vesperas & \\
\hline \multirow[t]{2}{*}{ f. $33 v$} & Feria quinta. Ad Nocturnum & f. $40 \mathrm{v}$ \\
\hline & Ad Laudes Lux ecce surgit aurea- himan četvrtka »ferijalnog" & \\
\hline f. $34 \mathrm{r}$ & Ad vesperas (Fer VI?) & f. $41 \mathrm{r}$ \\
\hline \multirow[t]{2}{*}{ f. $34 \mathrm{v}$} & Feria VI ad nocturnum & f. $41 \mathrm{v}$ \\
\hline & (Feria VI?) Ad laudes & \\
\hline f. $35 \mathrm{r}$ & Ad Vesperas & f. $1 \mathrm{r}$ \\
\hline \multirow[t]{2}{*}{ f. $35 \mathrm{v}$} & Sabbato. Ad Nocturnum & f. $1 \mathrm{v}$ \\
\hline & Ad Laudes & \\
\hline
\end{tabular}




\begin{tabular}{|c|c|c|}
\hline f. $36 \mathrm{r}$ & Ad Vesperas & f. $2 \mathrm{r}$ \\
\hline & $\begin{array}{l}\text { In Sabbato primae Dominicae de Adventu usque ad Vigiliam } \\
\text { Nativitatis Domini. Ad Vesperas ymnus }\end{array}$ & \\
\hline f. $36 v$ & Ad Matutinum & f. $2 v$ \\
\hline f. $37 \mathrm{r}$ & & f. $3 r$ \\
\hline f. $37 \mathrm{v}$ & & f. $3 v$ \\
\hline f. $38 \mathrm{r}$ & In vigilia Nativitatis Domini. Ad Vesperas ymnus & f. $4 \mathrm{r}$ \\
\hline f. $38 \mathrm{v}$ & Ad Nocturnum & f. $4 \mathrm{v}$ \\
\hline f. $39 \mathrm{r}$ & Ad Laudes (in tempore Nativitatis) & f. $5 r$ \\
\hline f. $39 \mathrm{v}$ & In Epiphania Domini. Ad Vesperas hymnus & f. $5 v$ \\
\hline f. $40 \mathrm{r}$ & $\begin{array}{l}\text { (Ad Vesperas) Hostis Herodis impiae- nastavak prethodnoga } \\
\text { himna }\end{array}$ & f. $6 r$ \\
\hline f. $40 \mathrm{v}$ & (In festis Beatae Mariae) Virginis - Ave Maris Stella & f. $6 \mathrm{v}$ \\
\hline f. $41 \mathrm{r}$ & Ad Nocturnum & f. $42 \mathrm{r}$ \\
\hline \multirow[t]{2}{*}{ f. $41 \mathrm{v}$} & Ad Laudes & f. $42 v$ \\
\hline & In Quadragesima (Ad Matutinum) & \\
\hline f. $42 \mathrm{r}$ & $(\ldots)$ & f. $43 \mathrm{r}$ \\
\hline f. $42 \mathrm{v}$ & In primo sabbato Quadragesimae & f. $43 \mathrm{v}$ \\
\hline f. $43 \mathrm{r}$ & In diebus dominicis ad Vesperas & f. $44 \mathrm{r}$ \\
\hline f. $43 \mathrm{v}$ & In sabbato dominicae de Passione & f. $44 \mathrm{v}$ \\
\hline f. $44 \mathrm{r}$ & & f. $45 \mathrm{r}$ \\
\hline f. $44 \mathrm{v}$ & Ad nocturnum hymnus & f. $45 \mathrm{v}$ \\
\hline f. $45 \mathrm{r}$ & Ad laudes hymnus (Veliki Petak) & f. $46 \mathrm{r}$ \\
\hline f. $45 \mathrm{v}$ & Sabbato post Pascha hymnus & f. $46 \mathrm{v}$ \\
\hline f. $46 \mathrm{r}$ & & f. $47 \mathrm{r}$ \\
\hline f. $46 \mathrm{v}$ & Ad nocturnum ymnus & f. $47 \mathrm{v}$ \\
\hline f. $47 \mathrm{r}$ & Ad laudes ymnus & f. $48 \mathrm{r}$ \\
\hline f. $47 \mathrm{v}$ & & f. $48 \mathrm{v}$ \\
\hline f. $48 \mathrm{r}$ & In Ascensione. Ad Vesperas et ad Laudes ymnus & f. $49 \mathrm{r}$ \\
\hline f. $48 \mathrm{v}$ & & f. $49 v$ \\
\hline f. $49 \mathrm{r}$ & Ad matutinum ymnus & f. $50 \mathrm{r}$ \\
\hline f. $49 \mathrm{v}$ & In die sanctum Pentecosten. Ad Vesperas & f. $50 \mathrm{v}$ \\
\hline f. 50r & Ad nocturnum ymпus & f. $51 \mathrm{r}$ \\
\hline
\end{tabular}




\begin{tabular}{|c|c|c|}
\hline f. $50 \mathrm{v}$ & & f. $51 \mathrm{v}$ \\
\hline f. $51 \mathrm{r}$ & Ad Laudes & f. $52 \mathrm{r}$ \\
\hline f. $51 \mathrm{v}$ & & f. $52 \mathrm{v}$ \\
\hline f. $52 \mathrm{r}$ & In festivitate Corporis et sanguinis Christi & f. $53 \mathrm{r}$ \\
\hline f. $52 \mathrm{v}$ & Ad nocturnum & f. $53 \mathrm{v}$ \\
\hline f. $53 \mathrm{r}$ & & f. $54 \mathrm{r}$ \\
\hline f. $53 \mathrm{v}$ & In laudibus & f. $54 \mathrm{v}$ \\
\hline f. $54 \mathrm{r}$ & & f. $55 \mathrm{r}$ \\
\hline f. $54 \mathrm{v}$ & In sancti Iohannis Baptistae & f. $55 \mathrm{v}$ \\
\hline f. $55 \mathrm{r}$ & & f. $56 \mathrm{r}$ \\
\hline f. $55 \mathrm{v}$ & & f. $56 \mathrm{v}$ \\
\hline f. $56 \mathrm{r}$ & In festo sancti Petri ad Vesperas et ad nocturnum ymnus & f. $57 \mathrm{r}$ \\
\hline \multirow[t]{2}{*}{ f. $56 v$} & Ad laudes & f. $57 \mathrm{v}$ \\
\hline & In nativitate sancti Pauli ad Vesperas et ad Matutinum hymnus & \\
\hline \multirow[t]{5}{*}{ f. $57 \mathrm{r}$} & Ad laudes (incipit solo) & f. $58 \mathrm{r}$ \\
\hline & In conversione Sancti Pauli & \\
\hline & Ad Vesperas & \\
\hline & Ad Laudes & \\
\hline & In cathedra Sancti Petri Ad Vesperas Ad nocturnum & \\
\hline f. $57 \mathrm{v}$ & & f. $58 \mathrm{v}$ \\
\hline f. $58 \mathrm{r}$ & In festo sanctae Mariae Magdalenae ad Laudes & f. $59 \mathrm{r}$ \\
\hline f. $58 \mathrm{v}$ & In matutino & f. $59 \mathrm{v}$ \\
\hline f. $59 \mathrm{r}$ & In laudibus & f. $60 \mathrm{r}$ \\
\hline f. $59 \mathrm{v}$ & In vinculis sancti Petri apostoli In Vesperis et in Matutinis ymnus & f. $60 \mathrm{v}$ \\
\hline \multirow[t]{2}{*}{ f. $60 \mathrm{r}$} & In laudibus & f. $61 \mathrm{r}$ \\
\hline & $\begin{array}{l}\text { In festo sancti Michaelis archangeli Ad Vesperas et ad Matutinum } \\
\text { hymnus }\end{array}$ & \\
\hline f. $60 \mathrm{v}$ & & f. $61 \mathrm{v}$ \\
\hline f. $61 \mathrm{r}$ & In laudibus ymnus & f. $62 \mathrm{r}$ \\
\hline f. $61 \mathrm{v}$ & In festo omnium sanctorum ad Vesperas et ad Nocturnum & f. $62 \mathrm{v}$ \\
\hline f. $62 \mathrm{r}$ & In laudibus & f. $63 \mathrm{r}$ \\
\hline f. $62 \mathrm{v}$ & In natali apostolorum. Ad Vesperas et ad Laudes ymnus & f. $63 \mathrm{v}$ \\
\hline f. $63 \mathrm{r}$ & In laudibus / cancellatum et sub texto inscriptum Ad matutinum & f. $64 \mathrm{r}$ \\
\hline
\end{tabular}




\begin{tabular}{|l|l|l|}
\hline f. $63 \mathrm{v}$ & In nativitate plurimorum martyrum Ad Vesperas & f. $64 \mathrm{v}$ \\
\hline f. $64 \mathrm{r}$ & & f. $65 \mathrm{r}$ \\
\hline f. $64 \mathrm{v}$ & Ad Matutinum & f. $65 \mathrm{v}$ \\
\hline f. $65 \mathrm{r}$ & In Laudibus & f. $66 \mathrm{r}$ \\
\hline f. $65 \mathrm{v}$ & In nativitate unius (martyris) & f. $66 \mathrm{v}$ \\
\hline f. $66 \mathrm{r}$ & Ad Laudes & f. $67 \mathrm{r}$ \\
\hline f. $66 \mathrm{v}$ & In nativitate confessorum. Ad Vesperas et Nocturnum ymmus & f. $67 \mathrm{v}$ \\
\hline f. $67 \mathrm{r}$ & & f. $68 \mathrm{r}$ \\
\hline f. $67 \mathrm{v}$ & In laudibus & f. $68 \mathrm{v}$ \\
\hline f. $68 \mathrm{r}$ & In confessorum (....unius???) ad Laudes & f. $69 \mathrm{r}$ \\
\hline f. $68 \mathrm{v}$ & In nativitate virginum. Ad Vesperas et ad Laudes ymnus & f. $69 \mathrm{v}$ \\
\hline f. $69 \mathrm{r}$ & Ad nocturnum ymnus & f. $70 \mathrm{r}$ \\
\hline f. $69 \mathrm{v}$ & In dedicatione ecclesiae. Ad Vesperas et ad Nocturnum & f. $70 \mathrm{v}$ \\
\hline f. $70 \mathrm{r}$ & In laudibus & f. $71 \mathrm{r}$ \\
\hline f. $70 \mathrm{v}$ & & f. $71 \mathrm{v}$ \\
\hline f. $71 \mathrm{r}$ & Incipiunt capitula per totum annum & f. $72 \mathrm{r}$ \\
\hline f. $71 \mathrm{v}$ & & f. $72 \mathrm{v}$ \\
\hline f. $72 \mathrm{r}$ & & f. $73 \mathrm{r}$ \\
\hline f. $72 \mathrm{v}$ & & f. $73 \mathrm{v}$ \\
\hline f. $73 \mathrm{r}$ & & f. $74 \mathrm{r}$ \\
\hline f. $73 \mathrm{v}$ & & f. $74 \mathrm{v}$ \\
\hline
\end{tabular}

List koji je u privremenoj numeraciji označen kao f. 7, a sadrži himan u čast sv. Klementu mučeniku, u predloženoj paginaciji u prvome stupcu nismo uzimali u obzir, jer nije pripadao kodeksu. Nekadašnji knjižničar, vjerojatno onaj koji je kodeks stavio uz Životopis sv. Klementa, taj je list očito držao dijelom kodeksa i u svom ga označivanju označio kao f. 1. Zbog toga dalje u radu koristimo isključivo naš prijedlog numeracije listova. Prema tekstualnomu sadržaju nakon utvrđene izvorne kodikološke strukture i numeracije koju smo uspostavili u prvome stupcu u tablici liturgijske strukture te na temelju značajki liturgijskoga sadržaja, možemo utvrditi da se kodeks sastoji od tri različita tipološka dijela: 
ff.1r-25v Antifonar ${ }^{14}$ (sadrži antifone)

ff. 26r-71r Himnar (sadrži himne)

ff. 71r-73v Kapitular (sadrži početke čitanja)

Razdjelne točke pojedinih tipoloških dijelova su i više nego jasne: sami pisari su upisali oznake koje nam pomažu u razlučivanju dijelova. Tako su početak i kraj Himnara izričito označeni: Incipit hymnarius na f. 26r, te Explicit hymnarius na f. 71r. Odmah ispod crvenim je slovima označen početak Kapitulara Incipiunt capitula per totum annum. Budući da početni dio Antifonara nedostaje, nije moguće utvrditi je li slično bio označen i taj dio kodeksa.

Na f. 26v moguće je vidjeti notno crtovlje u crvenoj boji, čija su tri reda pri dnu stranice prazna, odnosno bez upisanih melodija. Logično je zaključiti da su ta crtovlja bila predviđena za dodatno upisivanje antifona. Nakon završetka Antifonara tipološki započinje drugi dio kodeksa koji sadrži himne. Stilom pisanja, pa i notnim crtovljem, ovaj se dio razlikuje od stila pisanja i impostacije Antifonara; pritom ne mislimo samo na tip rukopisa nego i na impostaciju stranice - redaka teksta i notnoga crtovlja.

\subsection{Tematski dijelovi kodeksa}

\subsubsection{Antifonar}

Iz tekstualnog slijeda antifona, kao i iz kodikološke strukture očigledno je da u prvom dijelu kodeksa nedostaje jedan dio. Po strukturi kodeksa možemo reći da nedostaju početni listovi. Pokušali smo ih pronaći u Kaptolskomu arhivu, ali nismo uspjeli. Unatoč tome, nesporno je da je riječ o Antifonaru (tj. dijelu brevijara), jer - iako se antifone koriste u euharistijskome slavlju i slavlju ostalih sakramenata - ove su antifone zasigurno predviđene za slavlje službe časova. To je jasno iz označnica liturgijskih časova (npr. lat. ad tertiam, ad sextam, ad nonam...) pridodanih pojedinim antifonama kako bi se znalo u okviru kojega se liturgijskoga časa koriste predmetne antifone. Zbog navedenoga, naziv Antifonar držimo prikladnim.

\footnotetext{
${ }^{14}$ List koji smo u predloženoj numeraciji označili kao f. 1 sadrži himne, stoga bi bilo logično da je dio Himnara. Stil pisma i impostacija stranice su identični s ostalim listovima Antifonara. Zbog stila pisma i impostacije stranice, a i stoga što se radi o starijem dijelu kodeksa, držimo da je logično ostaviti ga kao prvi list kodeksa. Iako i ovo ostavlja dosta nejasnoća, u budućim istraživanjima se nadamo dobiti više razjašnjenja.
} 


\subsubsection{Himnar}

Drugi dio kodeksa započinje eksplicitno, naslov na f. 27r upućuje na to da je riječ o liturgijskim himnima. ${ }^{15}$ Nakon detaljnoga pregleda sadržaja ovoga dijela držimo da je i ovdje naslov prikladan. Himni su zapisani slijedeći ciklus liturgijske godine. Prije svakoga himna upisan je naslov blagdana u čijem slavlju se himan pjeva. Tekst prve strofe svakoga himna potpisan je pod notni zapis, koji je zapisan kvadratnim neumama unutar četverolinijskoga crtovlja. Ostale strofe su ispisane susljedno, ispunjajući svaki redak lista do kraja, tako da nova strofa ne mora započinjati u novome redu, već u bilo kojem dijelu retka na listu. Ipak, svaka nova strofa je označena crvenim inicijalom, što znači da je pisar vodio računa o preglednosti ali i praktičnosti.

Kao što je eksplicitno označen početak Himnara, tako je i njegov završetak jasno određen. U trećem redu na f. 71r izričito je napisano: Explicit liber hymnarii. Deo gratias. Amen. Ovakvo tematsko uređenje kodeksa povijesno je moguće obrazložiti. Prvi su himnari bili zasebne knjige, ali su - zbog praktičnosti - dodavani psaltirima, obično pri kraju, i to zajedno s čitanjima. Spajanje dvaju tipoloških dijelova možemo gledati kao proces razvoja nove zasebne liturgijske knjige, koja će se kasnije nazvati breviarium, časoslov. U našem kodeksu himni su dodani antifonama, ali uz njih ne postoji psaltir. Kao zasebna knjiga Himnar se sve manje upotrebljava razvojem i prepisivanjima časoslova te pomalo iščezava iz praktične uporabe, jer se himni u časoslovu nalaze uz pripadajuće liturgijske časove i blagdane. ${ }^{16}$ Ipak, kao zasebna liturgijska knjiga i dalje će nastaviti postojati, praktično sve do pojave tiska.

$\mathrm{Na}$ temelju usporedbe temporala i sanktorala unutar kodeksa, vidimo da se liturgijska struktura Antifonara i Himnara razlikuju. Kompilator koji je dijelove stavljao zajedno možda i nije vodio računa o tematskoj usklađenosti dijelova. Budući da je dio Antifonara izgubljen, bilo bi preuzetno dalje razvijati hipotezu.

\subsubsection{Kapitular}

Pojam Kapitular (lat. capitulare) u liturgijskoj terminologiji označava popis svetopisamskih čitanja označenih s početnim i završnim retkom ili dijelom retka (lat. incipit i explicit). Između uobičajeno dolazi prilog usque - do, sve

\footnotetext{
$\overline{15}$ »Himan je pjesnički način interpretacije liturgijskog časa ili svetkovine koja se slavi: često su himničke kompozicije vrlo lijepe sa literarnoga stajališta, ali i vrlo bogate teološkim sadržajem.«FOLSOM 1998: 295.

${ }^{16}$ FOLSOM 1998: 295.
} 
do, kojim je označeno da se određeno čitanje naznačeno u popisu, Kapitularu, čita iz samoga Svetoga pisma. U takvim popisima najprije se naznačivalo koji je liturgijski dan određeno čitanje, naslov biblijske knjige te početni i završni redak. ${ }^{17} \mathrm{U} K A S 463$ na ff. $72-75$ nalaze se naznake za čitanja u slavlju pojedinih liturgijskih časova. Naslovljen je Incipit capitula per totum annum. Dio je pisan manjim slovima od prethodnoga, ali očito pisar slijedi metodu prethodnoga dijela kojim se razlučuju pojedini odlomci, tj. svaki novi redak i odlomak počinje crvenim inicijalom. Osim što se navodi incipit čitanja, nakon njega je naveden otpjev s retkom, odnosno responzorij. Zbog toga je ovaj dio nešto teže označiti jednostavno kao Kapitular u najužemu smislu. ${ }^{18}$ Iz tekstualnoga se sadržaja ovoga dijela zaključuje da je riječ o Kapitularu časoslova.

\section{TIPOLOGIJA KODEKSA}

Pojedini dijelovi koje smo opisali (tj. Antifonar, Himnar i Kapitular), upućuju zajedno na knjigu koja se koristila u slavlju liturgije časova. Naime, glavni dio svakoga časoslova je psaltir, odnosno knjiga psalama, a ovdje psaltir nedostaje. Na temelju aktualnoga stanja kodeksa, ne možemo tvrditi da ga nije bilo, ali nemamo ni utemeljenih indicija da je postojao zajedno s dijelovima koji su se sačuvali. Psaltiri koji se čuvaju u Splitu i Trogiru, ${ }^{19}$ ne odaju možebitnih sličnosti s liturgijskom strukturom našega kodeksa. Na temelju sačuvanih dijelova kodeksa, njegove liturgijske strukture, kao i stila posljednjega napisanoga dijela (Capitulare), zaključujemo da se izvorno radilo o Antifonaru i Himnariju, dakle zbirci antifona i himana kojima su kasnijim prijepisima dodana čitanja, odnosno Kapitular.

Povijest razvoja liturgijskih knjiga ipak nam može osvijetliti pojedinosti na putu prema konačnoj tipologizaciji. Različita razdoblja u kojima su pojedini dijelovi napisani, te dodavani u naš kodeks, smješta ga u zasebnu skupinu liturgijskih knjiga koje posebno intenzivan razvoj imaju u srednjemu vijeku. Budući da su u knjizi različite sastavnice ukomponirane zajedno, jasno je kako sadrži više elemenata za slavlje liturgije časova. Korak dalje je u samoj liturgijskoj strukturi kodeksa, koju smo načinili prema naslovima liturgijskih vremena i formi. Analiza naslova već je tu pokazala neujednačenost u pravo-

${ }^{17}$ Kao primjer C. Vogel donosi: Die X mensis Maii. Natale sancti Gordiani. Scd. Matth. Cap $X C V$ (Mt 10,34-42) Nolite arbitrari quia veni pacem usque Amen dico vobis non percedet mercedem suam. Usp. VOGEL 1986: 314-316.

${ }^{18}$ NÜBOLD 1999: 33-34.

${ }^{19}$ Riznicu Trogirske katedrale usporedili smo radi blizine sa Splitom. 
pisnim formama naslova. ${ }^{20}$ Pored više pisara, ove nedosljednosti u pravopisu navode nas na zaključak da je kodeks prepisivan iz različitih izvora, tako u strukturi našega kodeksa imamo tzv. »čentonsku « formu, ${ }^{21}$ postupno su dodavani pojedini dijelovi kako se kodeks nadopunjavao za određene potrebe. Čije potrebe? Zajednice ili pojedinca? Iz strukture kodeksa možemo zaključiti da se radi o vrlo konkretnom pokušaju sistematizacije liturgijske knjige koju je, po svemu sudeći, koristila jedna osoba. Veličina kodeksa također upućuje na to da nije predviđen za korsku uporabu, odnosno kao knjiga koja je postavljena na korski stalak i iz koje bi svi mogli čitati jer su dimenzije korskih knjiga puno veće. Prisutnost samo antifona za pozivnik (lat. Invitatorium), te himana i čitanja (lekcijā) daju naslutiti kako je ovu knjigu možda koristio pojedinac koji bi, kao kantor, predvodio liturgiju časova. Ipak, ne možemo ništa sigurnije reći tko je mogao koristiti kodeks. Prisutnost franjevačkih svetaca može upućivati na redovnike, franjevce, ali nikako nije isključeno da ga je mogao koristiti i neki drugi, možda svjetovni svećenik, pa čak i neki redovnik koji nije franjevac.

Naposljetku, radi heterogenosti dijelova koji još ne pokazuju potpunu stilsku ujednačenost, kodeks bi se moglo tipologizirati kao jedan od primjeraka koji su još u razvoju prema potpuno usklađenoj formi časoslova. ${ }^{22}$

\subsection{Vrijeme nastanka kodeksa}

U određivanju vremena nastanka kodeksa ili njegovih dijelova, potrebno je voditi računa o više različitih elemenata: tip pisma te način pisanja, potom i tip notnih zapisa, odnosno neume, te, naposljetku, sam liturgijski sadržaj. Svaki od ovih elemenata ima svoje karakteristike iz kojih je moguće razlučiti određena razdoblja u procesu nastanka. Prema tipu pisma, barem prvi dio kodeksa (tanja slova), moguće je datirati i drugu polovinu, čak bliže kraju 13. stoljeća, ili u 14. stoljeće. I ostatak kodeksa je, također prema tipu pisma, moguće datirati u prvu polovinu 14. stoljeća. U ovoj stanovitoj širini, pa i nepreciznosti, sljedeća odrednica jest liturgijski sadržaj. Među pozivnicima (lat. Invitatorium) koje se nalaze u prvome dijelu, također su i one predviđene za blagdane sv. Franje Asiškoga i sv. Ante Padovanskoga. Sv. Franjo Asiški proglašen je svetim 1226. godine, sv. Ante Padovanski 1232., a časoslov u

${ }^{20}$ Često se pojam himan - lat. hymnus, pojavljuje kao ymnus, ali i kao hymnus. Također, nasuprot uobičajenom naslovu Jutarnje - Ad Laudes, f. 54v donosi naslov In Laudibus.

${ }^{21}$ Tal. centone - može se na hrvatski prevesti kao »stokrpa«.

${ }^{22}$ Moguće je, ali malo vjerojatno, da se radilo i možebitnome dijelu, ili dodatku psaltiru. 
njihovu čast je sastavio fra Julian iz Speyera ${ }^{23}$ najkasnije do 1247., tako da je ovaj rukopis u tom slučaju morao nastati nakon te godine, dakle u drugoj polovini 13. stoljeća. To je najraniji terminus post quem nakon kojega je nastao najstariji sloj kodeksa. Svakako, tip pisma svjedoči da je kodeks nastao i kasnije. Moramo uzeti u obzir i notne zapise: tip kvadratne notacije u prvomu dijelu kodeksa (do privremenoga f. 32v) datiran je kasno u 13., ili, vjerojatno, u 14. stoljeće. ${ }^{24}$ Tip pisma i notacije stoga nas navode na zaključak da je prvi dio kodeksa nastao oko 1300. godine, ili, vjerojatnije, nešto kasnije, ali svakako u prvoj polovini 14. stoljeća.

U drugom dijelu kodeksa, koji sadrži himne, osnovna referentna točka u dataciji je opet tip pisma, ali i neke liturgijske osobitosti. Drugi dio pisan je nešto masnijim slovima, debljim perom (calamusom). U ovom slučaju 14. stoljeće je izvjesno vrijeme nastanka drugoga dijela kodeksa. Kvadratnih neuma, koje se nalaze u ovome dijelu, datirane su svakako u 14., ili čak u 15. stoljeće. Tip pisma, dakle, pokazuje da je ovaj dio pisan tijekom 14. stoljeća na što nas, osim pisma, na to nas upućuje i liturgijska struktura. List, trenutačno označen f. 53r, donosi himan za svetkovinu Tijelova (lat. In festivitate Corporis et Sanguinis Christi). Budući da je tu svetkovinu za cijelu Crkvu uveo papa Ivan XXII. 1317. godine, taj dio kodeksa, kao i posljednji treći dio (Kapitular), morao je biti napisan nakon te godine. ${ }^{25}$ Gotičko pismo u dijelu Himnara koji prethodi ovome listu, također nas upućuje na četrnaesto stoljeće, ali, zbog sličnosti stila (iako su vidljive ruke različitih pisara) držimo da je cijeli drugi ali i treći dio nastao nakon 1317. god. Vrijeme do kojega je kodeks nastao teško je preciznije odrediti. Specifičnosti sanktorala ne dopuštaju nam nikakav detaljan zaključak, ili barem hipotezu. Jedini element određivanja terminusa ante quem, odnosno vremena do kojega je kodeks nastao, ostaju tip pisma i neuma. Kako je prethodno rečeno, neke je neume moguće datirati u prvu polovinu 15. stoljeća, pa bi to bilo krajnje vrijeme nastanka kodeksa. Iako je riječ o doista velikom vremenskom rasponu, stoga i nedovoljno preciznom, više od ovakve hipoteze zasad nije moguće izvesti.

${ }^{23}$ Njemački franjevac, pjesnik i kompozitor iz 13. stoljeća. Nije poznata godina njegova rođenja. Umro je 1250. u Parizu. Uz ostala djela sastavio je i Časoslov u čast sv. Franje i sv. Ante, koji se vrlo brzo raširio. Usp. Franciscus Liturgicus 2015: 21.

${ }^{24}$ Moguće da se ovaj tip neuma koristio već u 13. stoljeću, ali manja je vjerojatnost za to. 14. stoljeće je realna pretpostavka. Tipologiju kvadratne notacije napravila je prof. dr. sc. H. Breko-Kustura, nastavnica na Odsjeku za muzikologiju Muzičke akademije u Zagrebu, te članica i suradnica HAZU-a, na Odsjeku za povijest hrvatske glazbe.

${ }^{25}$ FRANK 1995: 172. 


\subsection{Lokalizacija}

Činjenice u pogledu tipa pisma mogu upućivati na zaključak da je kodeks, iako se čuva u Splitu, nastao u Italiji. S druge pak strane, vrlo je realna mogućnost da je kodeks nastao u nekom od prepisivačkih centara na hrvatskoj obali Jadrana, jer je u vrijeme nastanka glavnine kodeksa (14. stoljeće) na tom prostoru vidno razvijena prepisivačka djelatnost. ${ }^{26} \mathrm{U}$ sačuvanomu dijelu kodeksa, sanktoralne karakteristike ne upućuju na eventualno mjesto nastanka jer nema karakterističnih svetaca za područje Splita i okolice (npr. sv. Dujam). Sanktoralni sloj isprva se čini općenit za bilo kakve detaljnije zaključke. Bilo kakav leitmotiv je teško precizirati u aktualnomu zatečenome stanju. $\mathrm{Na}$ temelju onoga što je prisutno, moguće je sa zadrškom iznijeti hipotezu da se kodeks koristio u samome Splitu. Uz već spomenute franjevačke svece (sv. Franjo i sv. Ante), u kodeksu nalazimo i sv. Mariju Magdalenu. Prisutnost slavlja svih ovih svetaca u liturgijskom kodeksu razvijenoga srednjega vijeka nije neobična, ali - u nedostatku drugih izvora i eventualnih ostalih dijelova sanktorala - ne možemo se osloniti ni na kakvu drugu liturgijsku specifičnost. Svakako početci franjevačke prisutnosti u Splitu vežu se uz rane dvadesete godine 13. stoljeća, a sigurno od 1229. godine, od kada datira samostan sv. Frane na obali. ${ }^{27} \mathrm{U}$ njegovoj blizini, u Varošu iza samostana sv. Frane, postojala je i crkva posvećena sv. Mariji Magdaleni. ${ }^{28}$ Ipak nedostatak ostalih dijelova sanktorala ne dopušta ikakvu precizniju lokalizaciju.

\subsection{Naziv kodeksa}

Antifonar i Himnar zauzimaju najveći dio kodeksa, a Kapitular je naknadno dodan i pisan je manjim slovima te se nalazi na posljednja tri lista u kodeksu. Tipološka terminologija, kao i usporedbe s ostalim liturgijskim knjigama iz srednjega vijeka (koje su također sastavljene od različitih tematskih i tipoloških dijelova), pokazuju da se u označivanju, odnosno naslovljavanju takvih knjiga, naglašava tipologija koja je određena glavninom sadržaja. ${ }^{29}$ Daljnja

${ }^{26}$ BADURINA 1995: 7-11.

${ }^{27}$ ROŠČIĆ 2012: 22.

${ }^{28}$ BADURINA 2012. Možda su tu crkvicu posluživali franjevci.

${ }^{29}$ Kao primjer može poslužiti rukopis L 90 iz Kantonalne knjižnice u Freiburgu $(\mathrm{CH})$ koji je u naslovu tipologiziran kao Psalterium - Hymnarium Ordinis fratrum praedicatorum, iako mu je sadržaj sastavljen od više različitih dijelova. Tako u rukopisu koji ima 207 listova imamo sljedeće tipološke dijelove: Kalendar, Responsoriale, Tonar, Officium mortuorum, Psalterium feriatum, Hymanrium I, Hymnarium II, Officium Parvum BVM, Antiphonae »für kleinen Horen «. LEISIBACH 1976: 106-108. 
označnica srednjovjekovnih kodeksa u suvremenoj liturgijskoj i kodikološkoj metodologiji jest da se, pored tipoloških značajki, označavaju bilo po imenima osoba koje su ih koristile ili posjedovale,$^{30}$ bilo po mjestu gdje su korišteni ili gdje se čuvaju. ${ }^{31}$ Kako smo vidjeli o podrijetlu kodeksa KAS 463 nije moguće mnogo reći, ali čuva se u Splitu. Vodeći, stoga, računa o dosad navedenim elementima, kao i o liturgijskoj i tipološkoj strukturi, držimo da bi prikladan naziv kodeksa KAS 463 bio Antifonar i Himnar iz Splita, tj. Antiphonarium et Hymnarium spalatense.

\section{ZAKLJUČAK}

Na temelju istraživanja možemo zaključiti da je kodeks $K A S 463$ bio korišten u slavljima liturgije časova, po svemu sudeći u gradu Splitu. Moguće je da se njime služio neki redovnik koji je u svojoj zajednici imao službu i dužnost kantora, predvoditelja pjevanja i čitanja svetopisamskih tekstova. Obveza molitve časoslova kroz povijest Crkve je različito interpretirana i primjenjivana, ali općenito vrijedila je i za dijecezanske svećenike, kao i za redovnike i monahe. Notni zapisi u kodeksu govore da je bio korišten i za liturgijsko pjevanje. Stanje u kojemu smo ga zatekli, njegovo prvo predstavljanje, kao i istraživanje njegove liturgijske i kodikološke strukture, dali su neke odgovore na pitanja o tipu knjige kao i o nekim fazama njegova nastanka i uporabe iz povijesno-liturgijske perspektive. Spoznaje o tehničkim značajkama i liturgijskoj strukturi predstavljene u ovom radu mogu utrti put daljnjim istraživanjima kodeksa KAS 463 koja namjeravamo poduzeti. Među takva ulazi podrobna analiza stila pisma i neuma, kao i detaljnija povijesno-geografska analiza te, posljedično, usporedba s drugim kodeksima koji se čuvaju i(li) su nastali na istomu geografskome području u otprilike istomu vremenskome razdoblju.

\section{IZVORI}

DELL'ORO F. (ur.). 1985, Monumenta Liturgica Ecclesiae Tridentinae, sv. 2/B (Sacramentarium Adelpretianum). Trento: Società Studi Trentini di Scienze Storiche.

HÄNGGI A.; A. SCHÖNHERR (ur.). 1970. Sacramentarium Rhenaugiense. Freiburg: Universitätsverlag.

SEDDA F. (ur.). 2015. Franciscus Liturgicus. Milano - Padova - Perugia - Vicenza: Editrici francescane.

${ }^{30}$ Npr. Adalbertov sakramentar ili Sakramentar biskupa Adalberta. DELL'ORO 1985: 8751237.

${ }^{31}$ Npr. Sakramentar iz Rheinaua. HÄNGGI; SCHÖNHERR: 1970. 


\section{LITERATURA}

BADURINA, A. 1995. Illuminated manuscripts in Croatia. Zagreb: Kršćanska sadašnjost.

BADURINA, A. (ur.). Hagiotopografija Hrvatske (CD ROM). 2012. Zagreb: Kršćanska sadašnjost.

BATTELLI, G. 2015. Lezioni di paleografia. Città del Vaticano: Libreria Editrice Vaticana.

FOLSOM, C. 1998. I libri litrugici romani. A. Chupungco (ur.). Scientia liturgica, svezak 1, Casale Monferrato: Piemme, 263-330.

FRANK, K. S. 1995. Fronleichnam. W. Kasper (ur.). Lexikon für Theologie und Kirche, sv. 8. Freiburg - Basel - Rom - Wien: Herder, 172.

GREGORY, C. R. 1900. Textkritik des Neuen Testamentes. Leipzig: J. C. Hinrichs'sche Buchhandlung.

LEISIBACH, J. 1976. Die liturgischen Handschriften der Kantons- und Universitätsbibliothek, (Spicilegii Fribourgensis subsidia 15). Freiburg: Universitätsverlag Freiburg.

MANIACI, M. 1996. Terminologia del libro manoscritto. Roma-Milano: Istituto centrale per la patologia del libro editrice biliografica.

NÜBOLD, E. 1999. Perikopen. W. Kasper (ur.). Lexikon für Theologie und Kirche, sv. 8. Freiburg - Basel - Rom - Wien: Herder, 33-34.

PETRUCCI, A. 1992. Breve storia della scrittura latina. Roma: Bagatto Libri.

ROŠČIĆ, N. M. 2012. Samostan sv. Frane u Splitu, Zagreb - Split: Hrvatska provincija sv. Jeronima franjevaca konventualaca - Samostan sv. Frane Split.

VOGEL, C. 1986. Medieval liturgy. An introduction to the sources. Washington D. C., tr. W. G. Storey - N. K. Rasmussen, Pastoral press.

\section{Summary}

\section{Domagoj Volarević}

\section{MANUSCRIPT 463 OF THE CAPITOL ARCHIVE IN SPLIT (KAS 463)}

In the Capitol Archive of the Split-Makarska Archdiocese, under code number 463, there is a manuscript, a parchment codex written in Gothic script. The list of archival data, with a signature note, proves that the manuscript was previously known, and logically it should have been placed among the books and folders, but was not. As it usually happens with discoveries, the manuscript was found by chance, in late 2017. It was thought to be a completely unknown medieval codex. In February 2018, it was determined that the manuscript is precisely the one that had been previously archived under code number 463. It was discovered together with the manuscript containing St. Clement's biography from the $16^{\text {th }}$ century, and some older parts were noticed. These parts, considering their writing style and writing pad, could not belong to the original St. Clement's biography manuscript; they are much older. The primary analysis revealed that it was a medieval liturgical codex. The codex is restored and is now waiting to be hardbound. After restoration, liturgical and codicological analyses were carried out which contributed to the proper arrangement of the foil of the codex. The results of the latter analysis are provided below.

Keywords: codex, liturgy, hymn book, antiphonary, capitulary, codicology 


\section{PRILOZI}

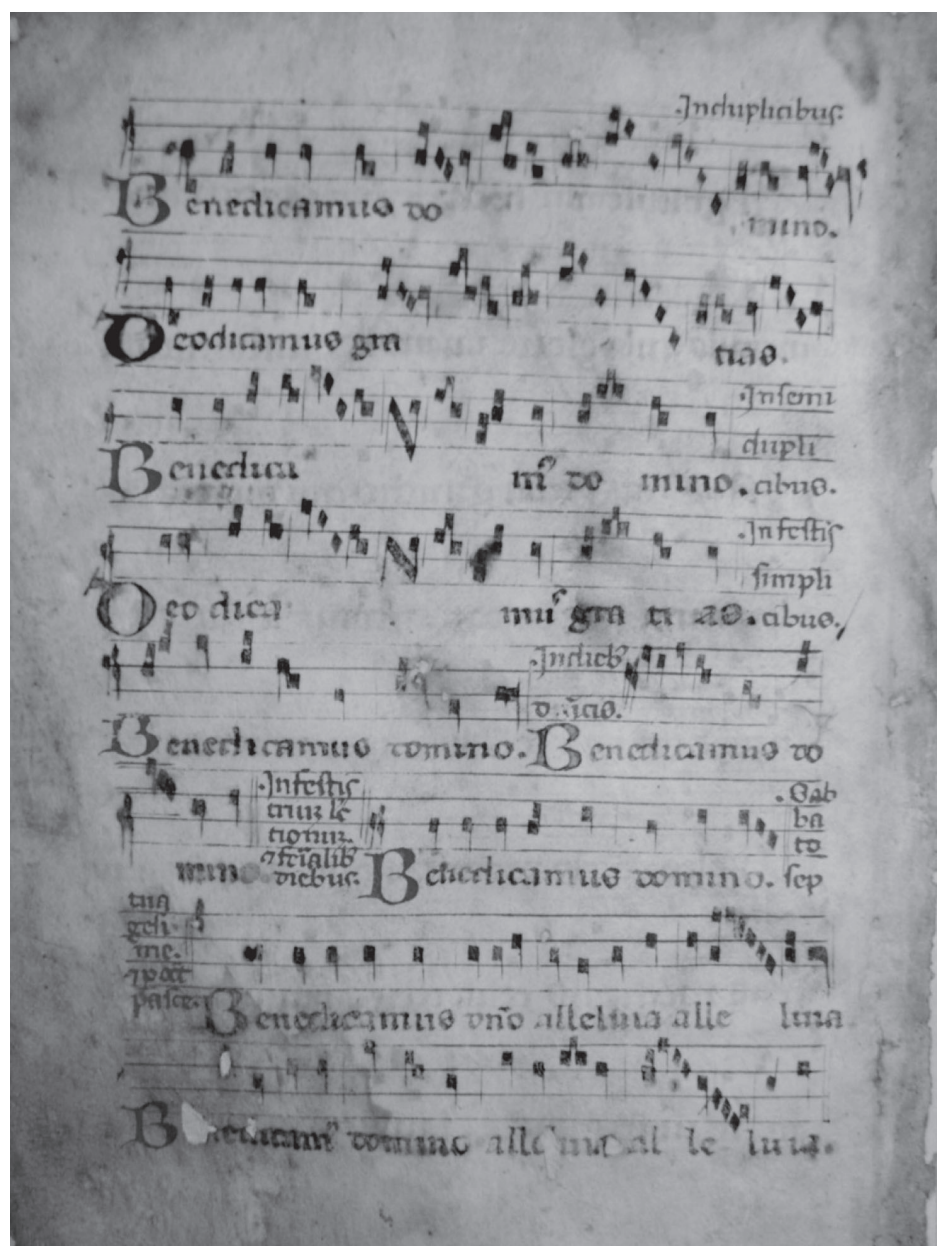

Slika 1. KAS 463 - f. 8v

Figure 1. KAS 463 - f. 8v 


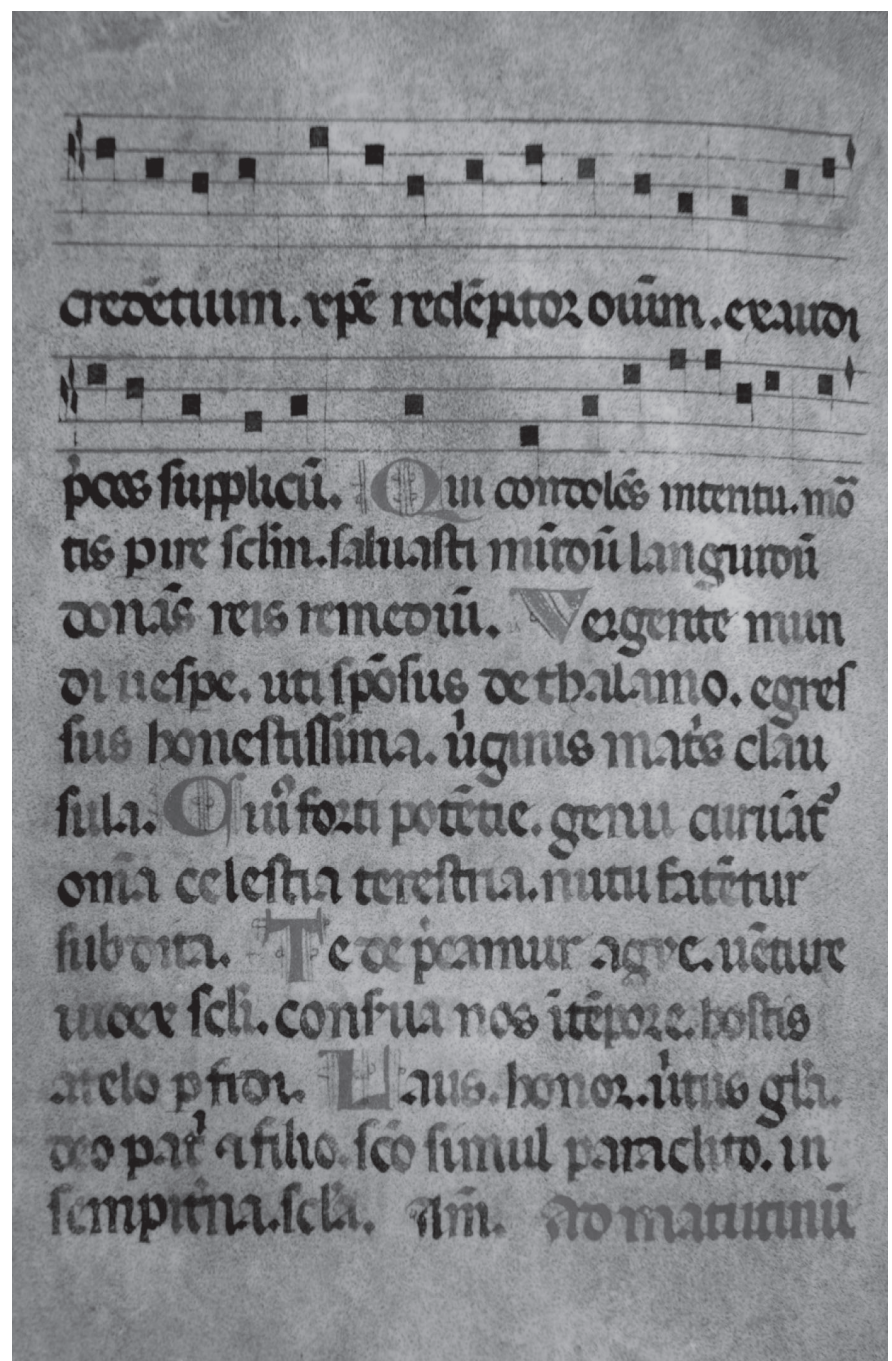

Slika 2. $K A S 463$ - f. 2v

Figure 2. KAS 463 - f. 2v

Domagoj Volarević

Catholic Faculty of Theology

Split (Croatia)

domagoj.volarevic@du.t-com.hr 